\title{
Water Supply in the Mojave River Ground-Water Basin, 1931-99, and the Benefits of Artificial Recharge
}

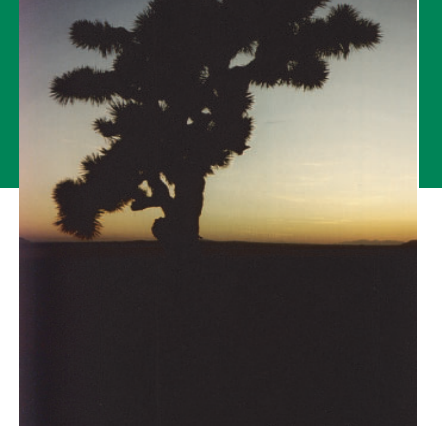

The Mojave River and the associated aquifer system are important water supplies in the Mojave Desert of southern California. The river and aquifer system are in hydraulic connection in many areas, and when flow conditions change in one, the other usually is affected. The river is an unpredictable source of water; therefore, residents of the basin rely almost entirely on ground water for their water supply. This reliance on ground water has resulted in overdraft conditions that have caused water-level declines, changes in the quantity and spatial distribution of recharge from the Mojave River, and loss of riparian habitat. The U.S. Geological Survey (USGS), in cooperation with the Mojave Water Agency (MWA), has completed several studies to determine the likely effects of overdraft on the ground-water and surfacewater relations along the Mojave River. This report summarizes those studies, highlighting some of the simulation results from a ground-water flow model, and describes the groundwater and surface-water conditions of the Mojave River Basin.

\section{Mojave River Ground-Water Basin}

The Mojave River ground-water basin is in the western part of the Mojave Desert and is about 80 miles northeast of Los Angeles, California. The basin encompasses about 1,400 square miles and is divided into six management subareas: Oeste, Este, Alto, Transition zone of the Alto (hereinafter referred to as the Transition zone subarea), Centro, and Baja (fig. 1). The major source of surface water and replenishment (recharge) to the ground-water system in the basin is the Mojave River, but the river is unreliable for direct water supply because its 100 miles of streambed is dry - except for a short reach of perennial flow and periods of flow after intense storms. Therefore,

Figure 1. Location of the study area and subareas of the Mojave River groundwater basin, southern California.

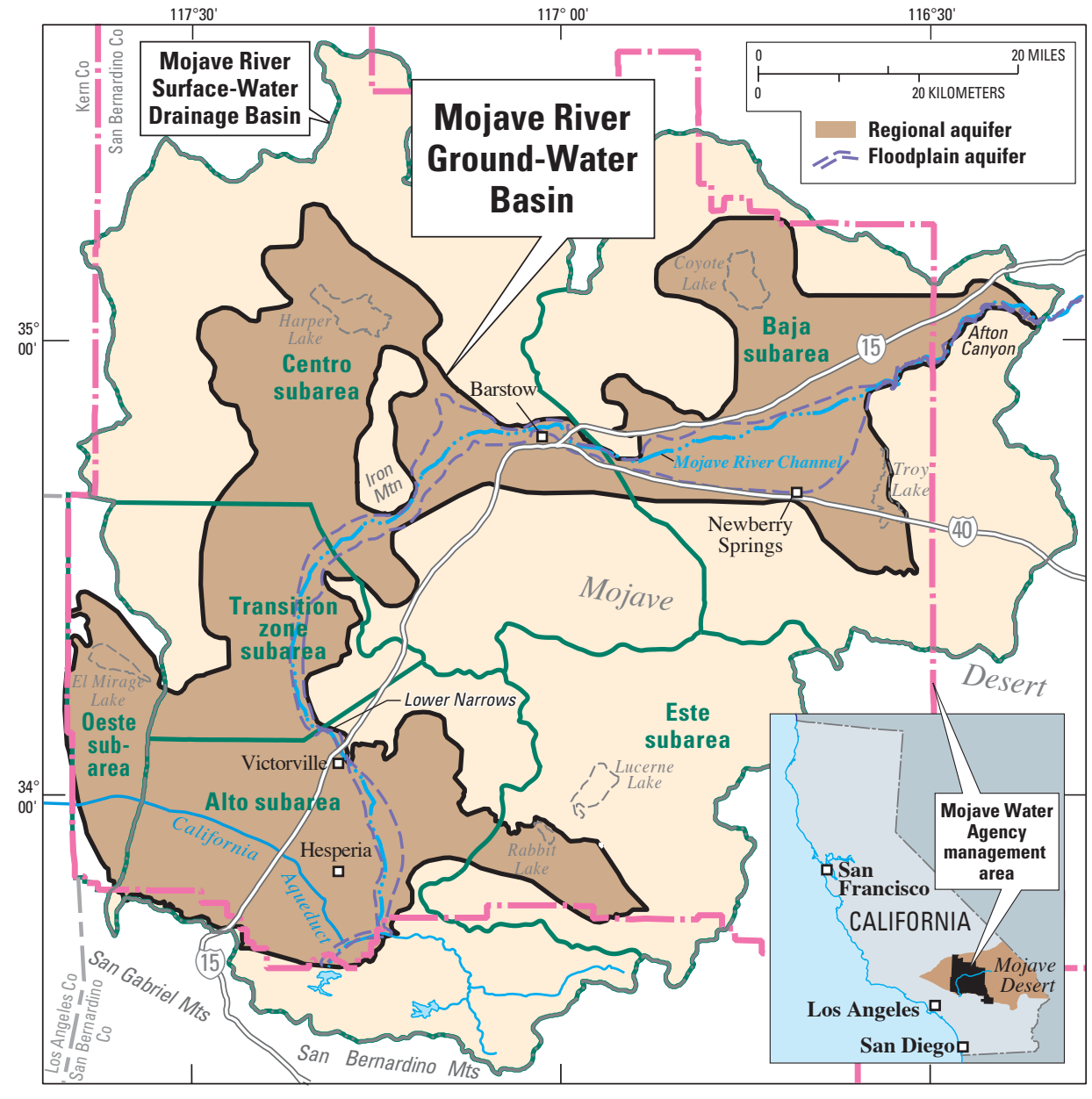

USGS Fact Sheet 122-01 November 2001 
residents of the basin rely almost entirely on ground water for their water supply, which has resulted in overdraft conditions. For the purposes of this report, overdraft occurs when ground-water discharge (natural discharge plus pumpage) exceeds recharge, resulting in a net reduction in ground water stored in the aquifer. The overdraft of the Mojave River ground-water basin has led to the adjudication of the basin. The complaint that led to the adjudication alleged that the cumulative water production upstream of the city of Barstow from 1931-90 (referred to as the adjudication period) had overdrafted the basin.

\section{Aquifer System}

The aquifer system in the Mojave River ground-water basin consists of two interconnected aquifers - a floodplain aquifer and a regional aquifer underlying and surrounding the floodplain aquifer (figs. 1 and 2). The floodplain aquifer, which is as much as 250 feet thick, is composed mainly of sand and gravel deposited by the Mojave River and extends beyond the recent floodplain in some areas. The flood- plain aquifer ranges in width from 120 feet at the Upper Narrows to more than 5 miles in parts of the Baja subarea (Stamos and others, 2001). The regional aquifer extends throughout most of the study area and consists mainly of sand, silt, and clay; the permeability of the aquifer decreases with depth. In general, the floodplain aquifer is more permeable than the regional aquifer. For a more detailed description of the aquifer system, see Stamos and others (2001) or visit http:// water.usgs.gov/pubs/wri/ wri014002.

\section{Source, Movement, and Age of Ground Water}

The primary source of natural recharge to the basin is the Mojave River. The river contributes more than 80 percent of the natural recharge to the basin and most of this contribution remains in the floodplain aquifer (Stamos and others, 2001). Some natural recharge also is from precipitation runoff that infiltrates the upper reaches of normally dry washes, and is referred to as mountainfront recharge. Essentially no mountain-front recharge occurs in areas away from the washes (Izbicki and others, 2000).

Mountain-front recharge moves over long distances through the regional aquifer and eventually discharges to the Mojave River after thousands of years. Results from isotopic analyses indicate that ground water sampled from the regional aquifer beneath the Mojave River entered the groundwater system more than 20,000 years ago (Izbicki and others, 1995).

\section{Hydraulic Connection between the Floodplain and Regional Aquifers}

The floodplain and regional aquifers have different hydrologic properties but they are connected hydraulically, that is, water and fluid pressure responses are transmitted between the aquifers. Pumpage and recharge cause changes in fluid pressure within one aquifer that can induce water to either move into, or out of, the other aquifer. The hydraulic connection between aquifers is supported by chemical and isotopic data which indicate that in areas near the river, the regional aquifer contains water that was

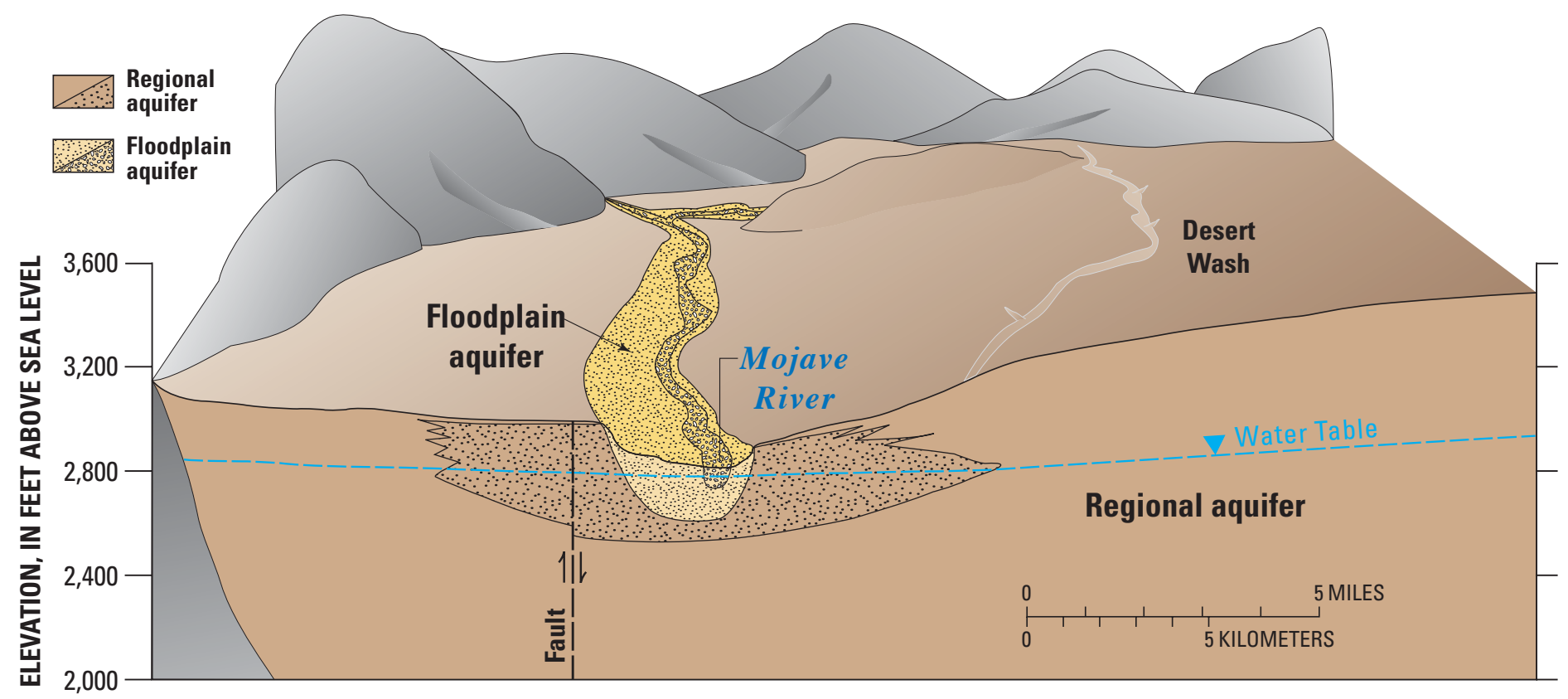

Figure 2. Conceptualized geologic section of the aquifer system. View is to the south in the Alto subarea. 
recharged by the Mojave River less than 50 years ago (Izbicki and others, 1995).

A ground-water flow model developed for the basin (Stamos and others, 2001) was used to evaluate how pumpage affected the rate and direction of flow between the floodplain and regional aquifers. In the Alto, Transition zone, and Baja subareas, the ground-water flowed from the regional aquifer to the floodplain aquifer during predevelopment conditions and from the floodplain aquifer to the regional aquifer (a reversal in flow direction) during the adjudication period of 1931-90 (fig. 3). In the Centro subarea, ground-water flowed from the floodplain aquifer to the regional aquifer during both periods, but the rate of flow increased significantly during the adjudication period (fig. 3 ).

\section{Pumpage and Changes in Ground-Water Storage}

Ground-water pumpage in the basin has increased with time, with a large increase starting in the late 1940s (fig. 4). Results from the ground-water flow model indicate that water was added to storage (storage accretion) from 1931 to the mid 1940s, and water was removed from storage (storage depletion) from the mid 1940s through 1999. The model results also indicate that overdraft started in the Centro and Baja subareas by the early 1950s, and was present in all subareas by 1960 (indicated by negative numbers in figure 4). By 1999, the cumulative amount of overdraft for the entire basin was about 2.5 million acre-feet, most of which occurred in the Centro (about 750,000 acre-feet) and Baja (about 1.1 million acre-feet) subareas (fig. 4).

Overdraft has caused changes in the quantity and spatial distribution of recharge from the
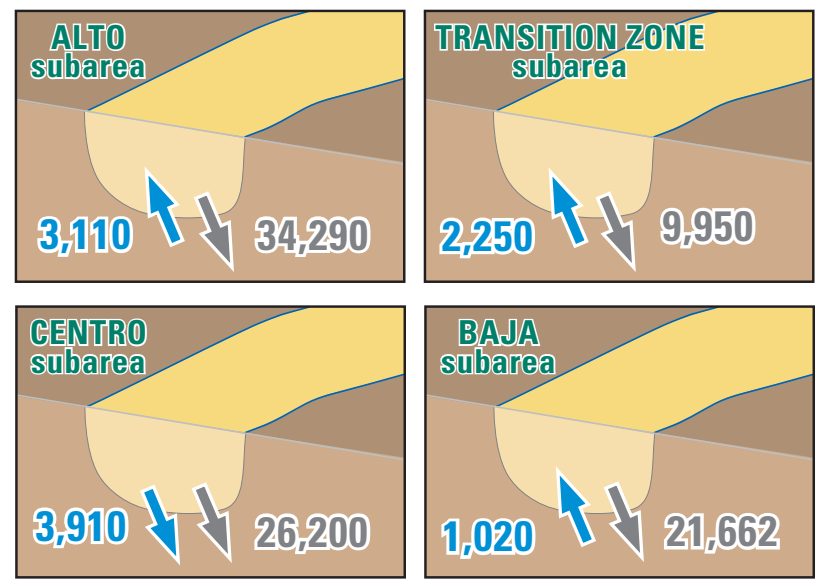

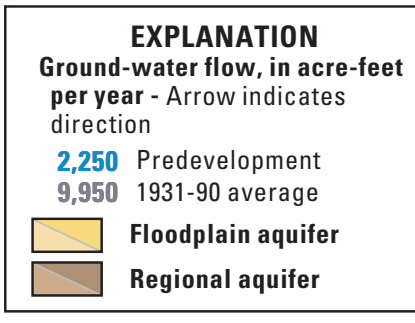

Figure 3. Simulated exchange of water between the floodplain aquifer and the regional aquifer for predevelopment and average 1931-90 conditions.
Mojave River (Stamos and others, 2001), loss of riparian habitat (Lines, 1996; Lines and Bilhorn, 1996) and water-level declines in wells (Stamos and others, 2001). Water levels have declined between 50 and 75 feet in the Alto subarea since the mid-1940s, about 100 feet in the Centro subarea near Harper Lake since the early 1960s, and almost 100 feet in the Baja subarea south of the river since the early 1930s (Stamos and others, 2001).

\section{Artificial Recharge}

To mitigate the effects of overdraft in the Mojave River ground-water basin, the MWA is using imported California State Water Project (SWP) water for artificial recharge by surface spreading. The ground-water flow model was used to simulate the effects of two artificial recharge alternatives for the period of 2000-2019 under drought conditions. Both alternatives assumed that flow in the Mojave River was equivalent to flow during the 20-year drought of 1945-64 and that annual pumpage was equivalent to the actual 1999 pumpage (166,000 acre-feet per year). The first simulation evaluated the alternative in which no water was available to artificially recharge the ground-water system during the drought. The second simulation evaluated the potential benefit of artificially recharging 65,000 acre-feet per year of SWP water at three existing and five

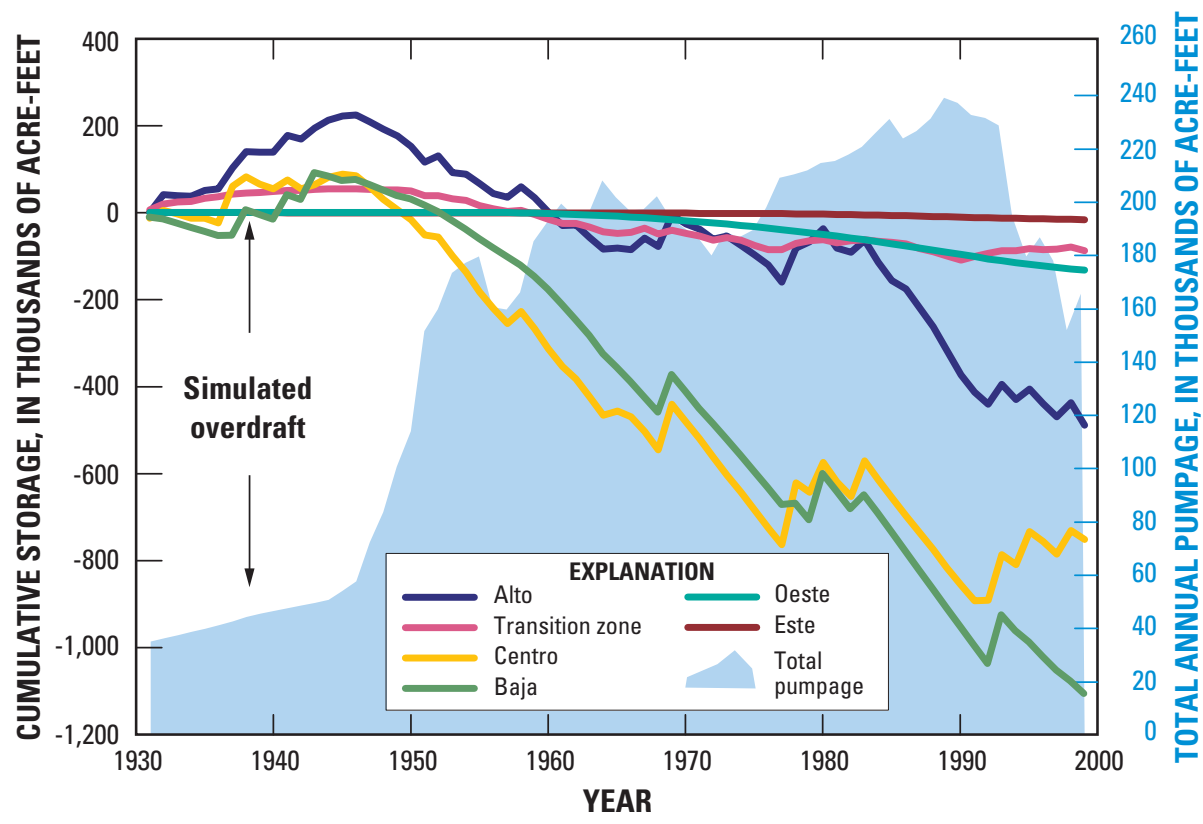

Figure 4. Cumulative simulated aquifer storage by subarea and total pumpage for all subareas, 1931-99. 
proposed recharge sites during the drought.

Simulation results indicate that when no SWP water was available for artificial recharge (the first alternative), water levels declined by as much as 60 feet after 20 years (fig. 5). However, when 65,000 acre-feet per year of SWP water was available for artificial recharge for 20 years (the second alternative), water levels were more than 100 feet higher near some of the artificial sites than if no artificial recharge was available (fig. 6). The increases in the waterlevels extended several miles into the regional aquifer from the point of recharge. For example, in the Alto subarea, water levels were more than 5 feet higher in the regional aquifer as far as 10 miles from the recharge site. These results show that artificial recharge can benefit the ground-water basin, and that artificial recharge can help mitigate the effects of overdraft, particularly when natural recharge to the ground-water system is limited.

To better understand the effects of the artificial recharge, the USGS has produced an animation that shows the spatial and temporal distribution of these water-level changes. The animation can be viewed at http://water.usgs.gov/ pubs/FS/fs-122-01.

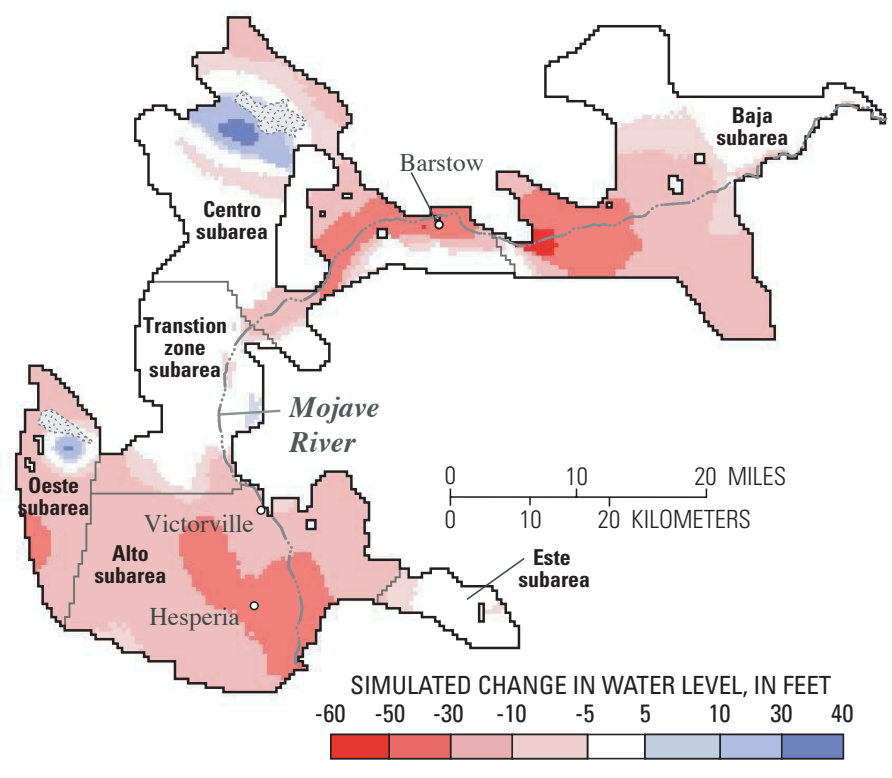

Figure 5. Simulated water-level change between 1999 and 2019 without artificial recharge.

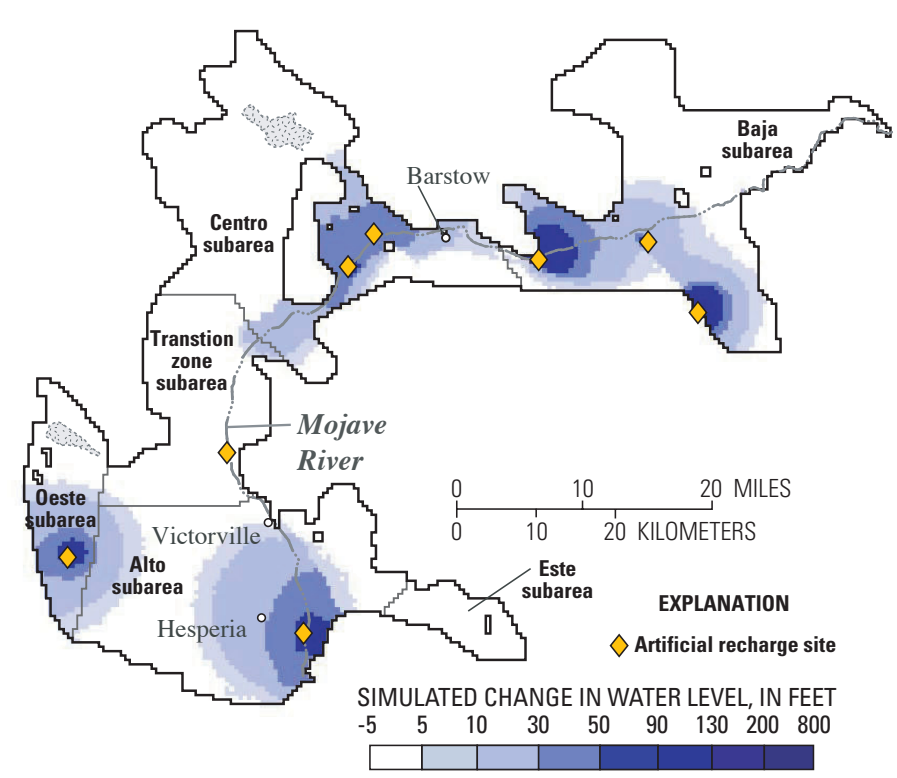

Figure 6. Difference between simulated 2019 water levels with artificial recharge, and 2019 simulated water levels without artificial recharge.

- C.L. Stamos, Tracy Nishikawa, and Peter Martin

\section{REFERENCES CITED:}

Izbicki, J.A., Martin, Peter, and Michel, R.L., 1995, Source, movement and age of groundwater in the upper part of the Mojave River basin, California, U.S.A., in Adar, E.M., and Leibundgut, Christian, eds., Application of tracers in arid zone hydrology: International Association of Hydrological Sciences, no. 232, p. 43-56.

Izbicki, J.A., Radyk, J.C., and Michel, R.L., 2000, Water movement through a thick unsaturated zone underlying an intermittent stream in western Mojave Desert, southern California, USA: Journal of Hydrology, v. 238, p. 194-217.

Lines, G.C., 1996, Ground-water and surface-water relations along the Mojave River, southern California: U.S. Geological Survey Water-Resources Investigations Report 95-4189, 43 p.

Lines, G.C., and Bilhorn, T.W., 1996, Riparian vegetation and its water use during 1995 along the Mojave River, southern California: U.S. Geological Survey Water-Resources Investigations Report 96-4241, 10 p., 1 pl.

Stamos, C.L., Martin, Peter, Nishikawa, Tracy, and Cox, B.F., 2001, Simulation of ground-water flow in the Mojave River Basin, California: U.S. Geological Survey Water-Resources Investigations Report 01-4002, 129 p.

\section{TECHNICAL CONTACT}

Christina L. Stamos

U.S. Geological Survey

5735 Kearny Villa Road, Suite O

San Diego, CA 92123-1135

e-mail: clstamos@usgs.gov

Voice: (858) 637-9005

Fax: (858) 637-9201

Califorina District activities website:

http://ca.water.usgs.gov

Cover photo courtesy J.A. Izbicki, USGS 